\title{
Casanova: real man or myth?
}

\section{Lesley Smith}

\section{Lovers throughout the ages}

One of the great fascinations of the study of medical history is the personalities that emerge from documents and manuscripts. When I ask a group to name a really famous lover from the pages of history, the cry "Casanova" heads the list virtually every time and, on some occasions, ends with him. There is a great gap between those individuals known for sexual exploits and those described as lovers. A time-machine meeting with Caligula or the Marquis de Sade could be a very uncomfortable half hour and although it could be accurately described as a sexual experience it would be likely to challenge the boundaries of even the most adventurous. The thought of meeting Casanova seems a much more appealing choice, particularly as it seems his first choice venue for seduction was in a perfumed Italian garden.

So what makes history record that an individual is a lover? Anthropologists and psychologists may give evidence as to what makes a person attractive in various cultures and time periods. We all realise that the extreme lines of a corseted Edwardian great aunt seem almost grotesque a century later. Shape, colouring and hygiene are influences that could make a modern man or woman a little reticent when faced with the reality of a prospective lover from the distant past.

Let us consider what other elements make up a fairly universal image of the successful Western lover. Power, influence and money all have aphrodisiac qualities for most people, whilst for others wit, charm and intelligence play a huge role. Physical beauty helps but does not seem to rank as highly as some might think. Consider a contemporary of Casanova's, Dr Samuel Johnson, who allegedly enjoyed considerable success with the opposite sex from the glittering intelligentsia of society. One glance at the portraits of the time of Johnson provides conclusive evidence that looks do not necessarily count in attracting the opposite sex. Those readers now irritated by the exclusive female view might consider that a number of French royal mistresses of the 18th century were morbidly obese by our standards and many wore wigs that were likely to be infested, as well as having foul breath and rotten teeth.

\section{Casanova: the man}

So what characteristics made up the real-life Casanova? One of the best-known pictorial images of him is cameostyle in profile, showing a formal grey powdered wig with a romantic bow at the back, slightly bulbous eyes and a strong, pointed nose. Perhaps not particularly striking but certainly pleasant in appearance. Apparently Casanova had some, if not all, of his teeth if his rounded cheeks tell a true story.

Giacomo Girolamo - the Casanova of fact, not fiction was born in Venice on 2 April 1725. His name would come to be known across the Western world to mean daring and

J Fam Plann Reprod Health Care 2009; 35(3): 201-202

Tutbury Castle, Tutbury, UK

Lesley Smith, Curator

Correspondence to: Lesley Smith, Tutbury Castle, Tutbury, Staffordshire DE13 9JF, UK. E-mail: info@tutburycastle.com outrageous, even criminal, but most of all the name Casanova would conjure up an image of "Lover".

The real Casanova was actually rather more fantastic as a man than even the most optimistic author could hope for. He was a real Renaissance creature in the time of Enlightenment. Bright as a child, he was extremely well educated, having initially been brought up with a doctor after the death of his father (his mother was an actress). He then studied at the University of Padua, which was followed by a job with a lawyer in Venice. He was tonsured and studied science and philosophy before receiving the four minor orders. His doctorate was bestowed from the University of Padua. Casanova could play the violin well enough to appear on stage in Venice: hardly a mean feat in a city with a proud arts heritage. Later in his life, Casanova was introduced to Mozart.

Despite his priestly background, Casanova dabbled in dark magic and kept company with black magicians. This crossing of spiritual powers was not unknown in the priesthood; doctors also practised what we may now view as 'white magic', while some even provided an occult service to wealthy clients for which they could be taken before the Ecclesiastical Courts for trial and punishment.

Casanova spent time in prison, once over a false bill of exchange, again when he was falsely accused of being involved in kidnap, and on yet another occasion for being implicated in abortion, which provides us with some evidence that he also acted as a quack doctor. It seems he was arrested on more than three occasions.

Casanova was a learned and prodigious writer: he once translated Homer's Illiad into Italian verse and wrote poems, plays and two enormous volumes about Polish history, having spent some time in that country. He also travelled widely - including to Paris, London, Berlin, Rome and St Petersburg - where he was welcomed, despite his chequered past, into the company of popes, kings and queens.

He was at certain times in his life hugely wealthy, once by virtue of organising the state lottery. Some historians believe he could have been a spy: certainly he mixed in all circles of life from royal gaming tables to the marketplace and was equally welcome in both. A perfect cover for a really professional spy with genuine charm felt by both men and women. We know he gave carefully chosen gifts, and took great care to provide a beautiful environment in which to carry out his conquests.

\section{Casanova: the lover}

If any men reading this article now feel that perhaps their life has not been as exciting as it could be, let us consider that we haven't even discussed 'Casanova the lover' yet. Casanova describes in his autobiography how he felt the first sexual stirrings at age 9 years and then went on to lose his virginity at the age of 16 years. He enjoyed a level of success in seduction across a broad spectrum of women from aristocracy to maids. He even 'shared' a pair of nuns (some say sisters in the usual sense) with an Abbé when he was 28 years old.

When one reads how brilliant this man was at both the arts and sciences, as well as being witty and often rich, we can see that even with the pleasant looks he enjoyed (like his mother who was a celebrated beauty), it is hardly surprising he was very attractive and, it appears, genuinely loved. 
The real reason that Casanova was successful was his reputation as an adventurer and lover. Women didn't seem to mind that they were one of many, and it is written that he was also very popular in the company of husbands who didn't seem to resent this extraordinary man. Some records seem to suggest that if Casanova desired or even won a wife then this was a matter of pride for the husband concerned. Casanova was fashionable, which made him a desirable accessory despite his occasional slips off the wheel of fortune. Indeed it is likely that his periods in prison enhanced rather than diminished his attractiveness. One can imagine the fluttering behind fans when the rumour circulated in 1756 that he had escaped from prison in Venice by slipping across the ducal roofs by moonlight.

Morals were not at all as they are today in the upper ranks of society. Affairs amongst married people seemed to be quite usual and that was also the case in England. This was a time in London when close to Covent Garden (once a Convent Garden) was the 'Chuckpenny Arcade' where guests were invited to stand a measured distance on a mat and throw coins into the vagina of a naked, bending prostitute. The prostitute, it is suggested, was able to keep the coins she managed to hold and the publican kept the fallen ones.

\section{Casanova: the author}

How do we know so much about Casanova? There are many books, court reports and papers but also we have his own memoirs. These tell us of a three in a bed romp between two female lovers: "intoxicated by voluptuousness ... and transported by continual fits of rapture - wreaked havoc on everything visible and palpable given to us by Nature, openly devouring everything we saw, and finding that we had all three become of the same sex in all the trios we performed". These memoirs, if published today about a well-known public figure, would cause a considerable stir in the national press.

Like most men at some point in their lives, Casanova struggled with impotence, which started to show itself in his forties. However, if calculated accurately, it appears that Casanova had sexual relations with about 130 women. History does not provide us with an answer as to why he had a particular attraction for women who dressed as men, but this was certainly the case according to his own written memoirs.
Casanova named his autobiography The Story of My Life. He died in 1798 at the age of 73 years, unmarried and leaving no acknowledged children. His manuscript was taken by a relative and published in 1822 translated into German in an 'adapted' format. It was subsequently translated into French in 1826. In 1945 the manuscript was saved from destruction and in 1960 the first edition of the true text of the original French manuscript was published by Brockhaus and Plon.

Casanova is careful, as a gentleman, not to name most of his conquests, which has led some observers to conclude that perhaps he was less than honest about his adventures and exploits. Some are keen to describe him as a disgusting libertine and a seducer of women but much of this criticism seems to fail as it seems these women wanted to be seduced by him. In understanding this highly charged sexual creature a not very scientific description applies: Casanova certainly had "IT" and it is very clear why.

\section{Future articles}

The next article in this series will describe the "Confessions of a Courtesan".

\section{Acknowledgement}

The author would like to thank $\mathrm{Dr}$ G Williams, British Museum, London, UK for his help and advice.

\section{Bibliography}

1 MacFarlane, Alan. Marriage and Love in England: 1300-1840. Oxford, UK: Wiley Blackwell, 1987.

2 Kelly, Ian. Casanova: Philosopher, Gambler, Lover, Priest. London, UK: Hodder \& Stoughton, 2008.

3 Masters, John. Casanova. New York, NY: Bernard Geis Associates, 1969.

4 Tomalin, Claire. Samuel Pepys: The Unequalled Self. London UK: Penguin, 2002.

5 Burford EJ, Wotton Joy. Private Vices - Public Virtues. London, UK: Robert Hale Ltd, 1995.

\section{About the author}

Lesley Smith is currently a postgraduate student in the Centre for the History of Medicine of the University of Birmingham, where she is developing a $\mathrm{PhD}$ in obstetrics and gynaecology in early modern Britain. She holds an honorary degree for "services to history". She makes 200-300 public appearances a year and also works as a TV historian in the UK and abroad including the USA. Lesley is also Curator of Tutbury Castle in Staffordshire and is currently involved with a major research project with the British Museum, which is her excuse for why it is taking her so long to finish her PhD!

\section{NEWS ROUNDUP}

\section{Inequality of access to cervical} screening across the UK

Marie Stopes International is calling for the National Health Service (NHS) cervical screening programme to be standardised across the UK, so that all women start testing from the age of 20 years. Currently screening begins at age 20 for women in Scotland, Wales and Northern Ireland, but women in England have to wait until they are 25. "The recent high profile case of Jade Goody, [with] the most virulent form of cervical cancer at just age 27 shows that this disease, whilst extremely rare among women under 30 , is nevertheless a potential threat", said Liz Davies, Marie Stopes International's Director of UK and Europe. "Smoking and having unprotected sex from an early age can increase the risk of developing cervical abnormalities." The National Cervical Screening Programme has seen death rates from this form of cancer plummeting by $70 \%$ over the past 30 years. Health minister, Ann Keen MP, recently announced that the Department of Health will continue to review the case for lowering the age for cervical screening to start in England. The concern is that vaccination against HPV may lead to a false sense of security. "The vaccination only protects against certain forms of the HPV virus, which is the major cause of cervical cancer", said Ms Davies. "Our fear is that young girls who are being vaccinated now may think they are completely protected, which simply is not the case. It makes sense to start them thinking about their cervical health as early as possible, and universal screening from the age of 20 is a key strategy in achieving that.'

For information see www.mariestopes.org.uk. For help and support visit www.jotrust.co.uk

\section{Dissatisfaction with contraception choice}

Despite the range of contraception available, the fpa (Family Planning Association) estimate that up to 2 million UK women are using a form of contraception with which they are unhappy. Lack of time or information and fear of weight gain are reasons cited by the fpa, who are currently running a campaign Finding the Perfect Partner (Choose What You Use) to promote greater control over contraceptive choice among women and health professionals. According to recent figures from the fpa, almost one in three UK women aged 18-49 years typically spends up to just 5 minutes selecting a suitable contraceptive method to use. Yet, almost half of these women $(47 \%)$ have had a pregnancy scare (thinking they were or could be pregnant when they didn't want to be). Putting on weight was the most common reason given by women for not wanting to use a particular method. Mood changes/swings were listed as second, knowing someone who had a bad experience using it was third, with not having enough information coming in as fourth. Being put off having sex was only cited as the fifth reason for being put off a particular contraceptive method.

Source: www.fpa.org.uk

Reviewed by Henrietta Hughes, MRCGP, DFSRH General Practitioner, London, UK 